Article

\title{
Transnationalism and Belonging: The Case of Moroccan Entrepreneurs in Amsterdam and Milan
}

\author{
Giacomo Solano ${ }^{1,2,3, *}$, Raffaele Vacca ${ }^{4}$, Matteo Gagliolo ${ }^{5}$ and Dirk Jacobs ${ }^{5}$ \\ 1 Migration Policy Group, 1030 Brussels, Belgium; E-Mail: gsolano@migpolgroup.com \\ 2 Department of Sociology and Social Research, University of Milan-Bicocca, 20126 Milan, Italy \\ ${ }^{3}$ Amsterdam Institute for Social Science Research, University of Amsterdam, 1018 WV Amsterdam, The Netherlands \\ ${ }^{4}$ Department of Sociology and Criminology \& Law, University of Florida, Gainesville, FL 32611, USA; E-Mail: r.vacca@ufl.edu \\ ${ }^{5}$ Group for Research on Ethnic Relations, Migration \& Equality (GERME), Faculty of Philosophy and Social Sciences, \\ Université Libre de Bruxelles, 1050 Brussels, Belgium; E-Mails: mgagliol@ulb.ac.be (M.G.), dirk.jacobs@ulb.ac.be (D.J.)
}

* Corresponding author

Submitted: 12 September 2019 | Accepted: 25 November 2019 | Published: 25 March 2020

\begin{abstract}
Research on migrant transnationalism has mostly focused on particular transnational activities, their salience in various contexts and populations, and their relationship with migrant incorporation. Less attention has been paid to the interplay between the different domains of transnationalism (economic, political, and socio-relational) and to the way in which they affect migrants' identity. This study investigates whether and how one domain of migrant transnationalism-transnational entrepreneurship-influences migrants' (1) transnational involvement in other domains and (2) sense of belonging to different social groups and places. Focusing on the case of Moroccan entrepreneurs in Amsterdam, the Netherlands, and Milan, Italy, we compare transnational migrant entrepreneurs, whose business is based on cross-border relationships and exchanges, with domestic migrant entrepreneurs, who are active exclusively in the destination country. Combining quantitative and qualitative data, we find that transnational entrepreneurs differ from domestic entrepreneurs mostly in terms of socio-relational transnational involvement. On the other hand, transnational entrepreneurship does not substantially change transnational practices in other domains or sense of belonging among Moroccan migrants.
\end{abstract}

\section{Keywords}

belonging; migrant entrepreneurship; Moroccan migrants; transnational entrepreneurship; transnationalism

\section{Issue}

This article is part of the issue "Boundary Spanning and Reconstitution: Migration, Community and Belonging" edited by Anya Ahmed (University of Salford, UK).

(C) 2020 by the authors; licensee Cogitatio (Lisbon, Portugal). This article is licensed under a Creative Commons Attribution 4.0 International License (CC BY).

\section{Introduction}

This article examines transnationalism and sense of belonging among Moroccan migrant entrepreneurs in two increasingly central immigrant destinations in Europe, namely Amsterdam, in the Netherlands, and Milan, in Italy. Taking in consideration transnational involvement in both entrepreneurial activities and other domains, we compare transnational migrant entrepreneurs, whose businesses are based on cross-border exchanges (e.g., regular import/export of goods and services with other countries), with domestic migrant entrepreneurs, who are mostly active in the domestic market of the destination country.

Transnational migrant entrepreneurship has been the subject of one of the most promising research areas on migrant transnationalism in recent years (Ambrosini, 2012). However, little research has been conducted on the ways in which transnational entrepreneurship affects migrants' transnational activities in other domains 
and their sense of belonging (Rath, Solano, \& Schutjens, 2020). In the broader field of transnationalism studies, research on migrant transnationalism has mostly focused on specific transnational practices, their salience in various contexts and populations, and their relationship with migrant incorporation. We know less about the interplay between transnational practices in different domains (e.g., the economic, socio-cultural, and political domain), and their relationship with migrants' sense of belonging (Diaz-Chorne, Suárez-Lledó, \& Rodriguez, 2019; Portes, Guarnizo, \& Haller, 2002; Snel, 't Hart, \& van Bochove, 2016; Tsuda, 2012). Furthermore, the large majority of studies on transnational entrepreneurship have focused on transnational relationships between $\mathrm{mi}-$ grants and their origin countries, while links with third countries (other than origin and destination) have been mostly ignored (Rath et al., 2020; Solano, 2016a, 2019).

The mixed-methods research presented in this article aims to address these gaps by investigating how transnational entrepreneurship influences migrants' sense of belonging and transnational practices in various domains, involving both the origin country and third countries. Our contribution is threefold. First, we provide new insights on the interplay between transnational behaviours in different domains and between migrants' transnationalism and sense of belonging. Second, while existing literature on migrant entrepreneurship often focuses on economic and business-related transnational practices among migrant entrepreneurs, we examine noneconomic transnational behaviours and sense of belonging in this population. Third, unlike most existing studies of migrant transnationalism, we extend the analysis to transnational practices involving both migrants' countries of origin and third countries.

After presenting our theoretical framework and previous research on the topic, we introduce the methodological approach of this research, report the findings, and conclude with a discussion of the main results.

\section{Background: Migrant Transnationalism}

In the last three decades, researchers of migrant transnationalism have extensively analysed the varied and continuing relationships between migrants and their origin societies in the cultural, social, economic, and political domains (Levitt \& Jaworsky, 2007). Today, international migrants are known to preserve and cultivate networks of relatives, friends and other acquaintances in sending countries, and to often maintain active roles in the economies, politics, and cultures of their origin societies (Levitt \& Jaworsky, 2007; Vacca, Solano, Lubbers, Molina, \& McCarty, 2018). These "here and there" relationships and interactions also shape migrants' identities (Boccagni, 2012), leading certain migrants to develop multiple and multisite forms of belonging that cut across national borders (Ehrkamp, 2005). Consistently, previous literature on migrant transnationalism has studied both the ways of being (transnational practices and activities) and the ways of belonging (attitudes and identities) of transnational immigrants (Andreotti \& Solano, 2019; Boccagni, 2012; Erdal \& Oeppen, 2013).

\subsection{Transnational Practices}

Migrants' transnational practices have different degrees of frequency and involve different domains. Existing literature identifies three main domains of transnational involvement (Guarnizo, Portes, \& Haller, 2003; Portes et al., 2002; Snel, Engbersen, \& Leerkes, 2006):

- The economic domain refers to migrants' economic activities involving their origin country and/or third countries, including economic exchanges and mobilisation of resources and contacts across national borders. Examples of economic transnationalism are financial remittances to communities of origin, cross-border investments in sending countries, and transnational businesses;

- The political domain refers to migrants' participation in the politics of their origin country, with practices such as voting in elections or establishing political organisations linked to political parties in the origin country;

- The socio-relational domain (sometimes labelled as "sociocultural") refers to the maintenance of social ties between migrants and contacts in the origin country or in third countries, and to migrants' participation in cultural initiatives (such as sports events or religious festivals) which take place in, or are otherwise strongly connected to, the origin country.

Intersecting with this three-way categorisation of transnational activities, González-Rábago and Blanco (2016) describe two additional, cross-cutting dimensions of migrant transnationalism: the degree of transnational involvement, which can take the form of a broad interest or specific and concrete actions; and the sphere where transnational practices take place, which can be the personal or the social sphere. Based on these two dimensions, four types of transnational practices can be identified: personal interest (e.g., interactions with family members in the origin country); social interest (e.g., seeking information on the origin country's political situation in the media); personal action (e.g., visiting relatives and friends, sending financial remittances); social action (e.g., voting at national elections, participating in political associations in the origin country).

Different degrees and types of migrant transnationalism are also described by Engbersen, Leerkes, Grabowska-Lusinska, Snel, and Burgers (2013) in their study of labour migration and transnational practices of Central and Eastern European migrants. They identify four different types of migrants, including two which are particularly relevant to our analysis: "bi-nationals," 
with strong links and attachments to both the origin and the destination country; and "settlers," with weak links and attachments to the origin country. In our study, transnational Moroccan entrepreneurs are analogous to bi-national immigrants in this classification, while domestic Moroccan entrepreneurs are comparable to the settlers.

Migrants may be involved in transnational activities in one or more domains (Levitt, 2001). Some literature suggests that the different domains of transnational practices tend to be linked, with the involvement in one domain increasing activity in another (Engbersen et al., 2013; Guarnizo et al., 2003; Portes et al., 2002; Snel et al., 2006, 2016; van Bochove, Rusinovic, \& Engbersen, 2010). For example, in their study of migrants in Rotterdam, the Netherlands, van Bochove et al. (2010) show that transnational economic activities (sending remittances or owning a house in the origin country) influenced transnational practices in other, non-economic domains. Yet very few studies have considered the question of whether and how conducting a transnational business, in particular, influences migrants' transnational practices in spheres other than entrepreneurial or economic activities. In one of these studies, Ren and Liu (2015) show that Chinese transnational entrepreneurs in Singapore are engaged in transnational political organisation and socio-cultural practices in China, as part of a strategy to accumulate economic and social resources.

\subsection{Sense of Belonging}

In addition to actions and behaviours in different domains, migrant transnationalism may also entail the redefinition of traditional identities and sense of belonging in multiple, multi-sited, and multi-scalar forms (Ehrkamp, 2005; Rouvoet, Eijberts, \& Ghorashi, 2017; Wotherspoon, 2018). Migrants establish attachments and affiliations with multiple social groups, linking to different sites (e.g., destination and origin countries), and involving different spatial scales (e.g., the national and the local scale). These identifications are not mutually exclusive (Phalet \& Swyngedouw, 2002). The identification with the origin country remains strong for most migrants, but it may coexist with identification with the destination country (Ehrkamp, 2005; Snel et al., 2016). Furthermore, in the destination country, migrants may develop forms of attachment at both the national and the local scale, such as the city or the neighbourhood (Jacobs, Phalet, \& Swyngedouw, 2006). Migrants may also strongly identify with different social groups which are not necessarily related to their national origin, such as migrants from other nationalities or particular groups of native-born people (e.g., professional or interest-based) in the destination country.

The potentially simultaneous attachments to different groups, places and scales, and the interplay between these and actual transnational behaviours have rarely been investigated (Tsuda, 2012). However, a substantial body of literature suggests that migrants' identities and sense of belonging are strictly linked to transnational activities (Ehrkamp, 2005; Groenewold \& de Valk, 2017; Ley, 2013; Louie, 2006; Snel et al., 2006, 2016). For example, research in the Netherlands shows that higher involvement in transnational activities is associated with stronger attachment of migrants to people in their origin country (Snel et al., 2016). Similarly, Louie (2006) demonstrates that frequent back-and-forth movements of Dominican immigrants in the US are associated with feelings of attachment to the Dominican Republic.

\section{Research Questions, Data and Methodology}

\subsection{Research Questions}

We study Moroccan entrepreneurs in Amsterdam and Milan to address two central research questions:

RQ1. How does transnational entrepreneurship influence transnational practices in other domains?

RQ2. How does transnational entrepreneurship shape migrants' sense of belonging?

We conceptualise migrant transnationalism as encompassing cross-border activities in the economic, political, or socio-relational domain, involving either the migrant's origin country (Morocco) or third countries (e.g., Belgium, France, United Arab Emirates, etc.). We expect that transnational entrepreneurs conduct more transnational activities in all domains compared to domestic entrepreneurs, as suggested by existing literature (Engbersen et al., 2013; Guarnizo et al., 2003; Portes et al., 2002; Ren \& Liu, 2015; van Bochove et al., 2010).

Furthermore, we hypothesise that transnational entrepreneurs develop a different sense of belonging compared to domestic entrepreneurs, consistent with existing research on transnationalism (Ehrkamp, 2005; Groenewold \& de Valk, 2017; Ley, 2013; Snel et al., 2006, 2016). In particular, we expect Moroccan transnational entrepreneurs to feel a stronger sense of identification with their origin country and co-nationals, compared to domestic entrepreneurs.

\subsection{Moroccan Migrant Entrepreneurs in Amsterdam and Milan: Sample and Descriptive Statistics}

We analyse data on first-generation Moroccan entrepreneurs in Amsterdam and Milan, including transnational and domestic entrepreneurs. Amsterdam and Milan are two particularly interesting contexts to study and compare, because their differences in migration history and migrant population may influence the activities and identities of migrant entrepreneurs in the two cities (Solano, 2016b). Amsterdam and the Netherlands have a longer, 60-year-old history as a migrant destination, with the pioneer Moroccan immigrants hav- 
ing arrived there in the 1960s. By contrast, the first Moroccan immigrants did not arrive in Milan and Italy until the late 1980s (Bijwaard, 2010; Colombo \& Sciortino, 2004). As a result, the migrant populations in the two cities are in part different. Both cities have a substantial number of migrant residents, but the number of people of Moroccan background is significantly higher in Amsterdam than in Milan. About 19,000 Moroccan immigrants lived in the Milan area in 2019 (0.7\% of the total population; Istat, 2019), compared to 77,000 Moroccan residents in the Amsterdam area ( $9 \%$ of the total population; Centraal Bureau voor de Statistiek, 2019). The relative numbers of migrant entrepreneurs slightly differ in the two cities, with migrant entrepreneurs being $33 \%$ of the whole immigrant population in Amsterdam (Rath \& Eurofound, 2011), and 29\% in Milan (Chamber of Commerce of Milan, 2019). There were about 3,100 Moroccan entrepreneurs in the Milan area in 2018 (Chamber of Commerce of Milan, 2019), representing $2.5 \%$ of all entrepreneurs in the city. While data on the national origin of migrant entrepreneurs are not available for Amsterdam, we know that there were about 8,400 Moroccan entrepreneurs in the Netherlands in 2009 (0.6\% of all entrepreneurs; Chamber of Commerce of Amsterdam, 2009).

The data for this study were collected from individual entrepreneurs and include information on individual experiences, strategies, practices, business relations, and resources and narratives of research participants. We employ a mixed-methods approach, analysing both individual survey data (e.g., about transnational practices) and in-depth qualitative interviews with migrant entrepreneurs.

Following qualitative typologies (Silverman, 2013), research participants were recruited to capture different types of business among Moroccan entrepreneurs. To obtain a comprehensive picture of Moroccan entrepreneurial activities in each city, four sources of participant contacts were used: (1) a list of entrepreneurs provided by the Milan Chamber of Commerce, with the indication of the business sector (e.g., import/export) and a short business description (no list was available for Amsterdam); (2) contacts from Moroccan associations with a significant role in the Moroccan communities of Amsterdam and Milan (e.g., Moroccan business networks and Islamic cultural associations); (3) entrepreneurs' business cards and advertisement materials left in shops and stores; and (4) Moroccan shops and stores that were visible in ethnic and central neighbourhoods of Amsterdam and Milan.

Seventy interviews were conducted in 2013-2014, with participants including transnational $(\mathrm{N}=35)$ and domestic ( $N=35$ ) entrepreneurs living in Amsterdam $(\mathrm{N}=30)$ and Milan $(\mathrm{N}=40)$. Most research participants were male $(N=54)$, middle-aged (about 40 years old), with a medium-high level of education. This is in line with the sex, age, and education distributions in the most recent data from OECD (2010) about migrant entrepreneurs in Italy and the Netherlands. Following suggestions from previous research on migrant entrepreneurship (Rath \& Schutjens, 2016), we recruited entrepreneurs in both the goods $(\mathrm{N}=45)$ and services $(N=25)$ sectors, and with both ethnic $(N=27)$ and nonethnic or mainstream ( $N=43$ ) businesses. Participants usually owned small businesses, with only a minority of them (less than 20\%) having more than four employees.

\subsection{Measures and Analyses}

The main goal of our analysis is to compare transnational and domestic Moroccan entrepreneurs in terms of transnational involvement and sense of belonging. Thus, our first set of dependent variables consists of measures of transnational involvement. We measure transnational practices in three different domains: economic, political, and socio-relational. In addition, we distinguish between transnational practices related to the origin country and those involving a third country. First, we collected information on different types of economic transnational practices (not directly related to the migrant's business), such as sending financial remittances, making financial investments, or owning property in the origin country or third countries. Second, we use measures of political transnational practices that capture political participation and interest in the origin country, such as reading newspapers about origin country politics, participating in social and political actions and associations linked to the origin country, or voting in origin country elections. Third, we employ measures of socio-relational transnational activities such as travels abroad (both in origin and third countries) not related to business, and regular contacts with friends and family abroad (a list of all survey items about transnational practices is in Table A1 in the Supplementary File).

We cross-classify transnational practices by domain (economic, political, or socio-relational) and by target country (Morocco or third country), resulting in five transnationalism indexes. For the political domain, we only consider practices related to Morocco, since there was no substantial level of transnational political activity involving a third country. Following a similar procedure to other transnationalism studies (e.g., Groenewold \& de Valk, 2017), the five indexes are sums of dummy items, each indicating whether the migrant conducts (1) or not (0) a certain transnational activity (see the Supplementary File for more details). Thus, the five indexes can be interpreted as a count of the number of different activities the migrant conducts for each transnationalism domain and target country (e.g., economic transnationalism involving Morocco for Index 1, sociorelational transnationalism involving third countries for Index 5).

Our second set of dependent variables consists of measures for the migrant's sense of belonging to different groups and places (see Table A2 in the Supplementary File for details). In line with existing mea- 
sures of attachment and belonging (e.g., Snel et al., 2006), we asked respondents to indicate to what extent they felt close to a given group or place on a scale from 0 to 10 . We considered the following four groups: natives of the destination country (i.e., Dutch people in the Amsterdam survey, Italian people in the Milan survey); Moroccan people in general; Moroccan people in the same destination country; and non-Moroccan immigrants in the same destination country. We also considered the following five places: the neighbourhood where the respondent lives; the city of destination; the city of origin; the country of immigration; and the origin country. Therefore, we have nine scales for sense of belonging, all treated as dependent variables.

Our main independent variable is whether or not the migrant entrepreneur conducts a transnational business, that is, one fundamentally based on cross-border exchanges and relationships. Following previous literature on transnational entrepreneurship (Portes et al., 2002; Rusinovic, 2008), our survey asked respondents whether a significant component of their business was based on relationships with Morocco or with countries other than the migrant's destination country (the Netherlands or (taly). To assess the validity of responses, answers to this key survey question were further probed in the subsequent in-depth, semi-structured interviews. Furthermore, the survey collected additional information on the type and degree of transnational business practices, for example with questions about businessrelated investments in Morocco, trade relationships with other countries, or the number of business-related travels abroad. Confirming the validity of the question we used to distinguish transnational and domestic entrepreneurs, our data show that, on average, entrepreneurs we classified as transnational are involved in four types of business-related transnational activities, while entrepreneurs we classified as domestic are involved in no business-related transnational activity (this difference is statistically significant; Wilcoxon rank-sum test $Z=-6.753, p$-value $=0.00)$.

Our indexes of transnational involvement and sense of belonging are non-normally distributed count variables. Therefore, we first use nonparametric bivariate tests (the Wilcoxon rank-sum test and the Wilcoxon matched-pairs signed-ranks test) to compare these indexes between transnational and domestic migrant entrepreneurs. Differences between transnational and domestic entrepreneurs, however, could be linked to intervening variables unrelated to transnational entrepreneurial activity, such as other business or personal characteristics (Brzozowski, Cucculelli, \& Surdej, 2017; Snel et al., 2016). To assess if this is the case, in addition to the bivariate analysis, we also present results from Poisson regression models for count dependent variables. These allow us to control for the potentially confounding effects of the following characteristics: business type (ethnic or mainstream business); business age (years since business initiation); city (Amsterdam or
Milan); sex of migrant (female or male); marital status of migrant (non-married or married); educational level of migrant (low-medium or high-medium); age at migration; number of years since migration; and number of close relatives the migrant has in the destination country. Additional results from negative binomial regression (not reported, available from the authors) show no overdispersion, indicating that Poisson regression is an appropriate modelling strategy for our dependent variables.

The quantitative analysis is integrated with an examination of the in-depth, qualitative interviews with migrant entrepreneurs, which shed more light on the reasons behind the differences between transnational and domestic entrepreneurs observed in the quantitative data. Throughout the interviews, respondents discussed a variety of reasons for their transnational practices. Respondents were also explicitly asked whether there had been any change in their transnational contacts and activities, or in their identification with specific groups and places, since they had started the business; what type of changes there had been; and whether they believed those changes to be related with their entrepreneurial activity.

\section{Findings: Transnationalism and Belonging among Transnational and Domestic Moroccan Entrepreneurs}

\subsection{How Does Transnational Entrepreneurship Influence Other Transnational Practices?}

Contrary to our expectations, transnational entrepreneurs exhibit significantly higher levels of transnational involvement than domestic entrepreneurs only in the socio-relational domain (with both the origin country and third countries), but not in the economic and political domains (Table 1). In particular, in comparison to domestic entrepreneurs, Moroccan transnational entrepreneurs spend more days in Morocco in a year and travel more frequently to their origin country. However, in the socio-relational domain, transnational entrepreneurs do not report more frequent contacts with either relatives or friends in Morocco.

However, while transnational and domestic entrepreneurs seem not to differ in terms of contacts with relatives (in Morocco or other countries) they are significantly different in terms of contacts with friends abroad (both Moroccan and of other nationalities), with transnational entrepreneurs reporting more frequent contacts. Furthermore, transnational entrepreneurs report to more frequently participate in development projects in Morocco compared to domestic entrepreneurs.

These differences hold when other business or individual characteristics are controlled for in Poisson regression models (Table 2). Being a transnational entrepreneur is significantly and positively associated with the degree of socio-relational transnational involvement with both Morocco and other countries. Figure 1 compares the index of socio-relational transnational involve- 
Table 1. Number of transnational practices by domains: transnational and domestic entrepreneurs.

\begin{tabular}{|c|c|c|c|c|}
\hline Transnational Practices & Median & Mean & $\mathbf{Z}$ & $\mathbf{p}$ \\
\hline \multicolumn{5}{|c|}{ Index of economic transnationalism-Morocco (0-4) } \\
\hline Domestic entrepreneurs & 1 & 1 & \multirow{2}{*}{-1.369} & \multirow{2}{*}{0.17} \\
\hline Transnational entrepreneurs & 1 & 1.34 & & \\
\hline \multicolumn{5}{|c|}{ Index of economic transnationalism-Other countries (0-4) } \\
\hline Domestic entrepreneurs & 0 & 0.09 & \multirow{2}{*}{-0.835} & \multirow{2}{*}{0.40} \\
\hline Transnational entrepreneurs & 0 & 0.17 & & \\
\hline \multicolumn{5}{|c|}{ Index of political transnationalism (0-5) } \\
\hline Domestic entrepreneurs & 1 & 1.08 & \multirow{2}{*}{-1.472} & \multirow{2}{*}{0.14} \\
\hline Transnational entrepreneurs & 1 & 1.23 & & \\
\hline \multicolumn{5}{|c|}{ Index of socio-relational transnationalism-Morocco (0-6) } \\
\hline Domestic entrepreneurs & 3 & 2.89 & \multirow{2}{*}{-2.427} & \multirow{2}{*}{0.02} \\
\hline Transnational entrepreneurs & 4 & 3.83 & & \\
\hline \multicolumn{5}{|c|}{ Participation in development projects in Morocco (0-1) } \\
\hline Domestic entrepreneurs & 0 & 0.09 & \multirow{2}{*}{-2.373} & \multirow{2}{*}{0.02} \\
\hline Transnational entrepreneurs & 0 & 0.32 & & \\
\hline \multicolumn{5}{|c|}{ Frequency of provision of support to people living in Morocco (0-3) } \\
\hline Domestic entrepreneurs & 1 & 0.86 & \multirow{2}{*}{-1.957} & \multirow{2}{*}{0.05} \\
\hline Transnational entrepreneurs & 1 & 1.29 & & \\
\hline \multicolumn{5}{|l|}{ Number of trips to Morocco } \\
\hline Domestic entrepreneurs & 1 & 1.03 & \multirow{2}{*}{-3.637} & \multirow{2}{*}{0.00} \\
\hline Transnational entrepreneurs & 2 & 2.34 & & \\
\hline \multicolumn{5}{|c|}{ Time spent in Morocco (days in a year) } \\
\hline Domestic entrepreneurs & 7 & 8.83 & \multirow{2}{*}{-3.289} & \multirow{2}{*}{0.01} \\
\hline Transnational entrepreneurs & 30 & 27.37 & & \\
\hline \multicolumn{5}{|c|}{ Index of socio-relational transnationalism-Other countries $(0-5)$} \\
\hline Domestic entrepreneurs & 1 & 1.14 & \multirow{2}{*}{-2.234} & \multirow{2}{*}{0.03} \\
\hline Transnational entrepreneurs & 2 & 1.91 & & \\
\hline \multicolumn{5}{|c|}{ Frequency of contacts with Moroccan friends in other countries } \\
\hline Domestic entrepreneurs & 0 & 0.54 & \multirow{2}{*}{-2.290} & \multirow{2}{*}{0.02} \\
\hline Transnational entrepreneurs & 1 & 1.17 & & \\
\hline Frequency of contacts with non-l & & & & \\
\hline Domestic entrepreneurs & 0 & 0.2 & & \\
\hline Transnational entrepreneurs & 1 & 0.94 & -3.381 & 0.00 \\
\hline
\end{tabular}

Notes: Specific transnational practices within each index are reported when the difference between transnational and domestic entrepreneurs is significant. See Table A3 in the Supplementary File for the complete results. $Z$ and $p$ are the test statistic and $p$-value, respectively, from Wilcoxon rank-sum tests. Bold p-value indicates test significance at $5 \%$ level.

ment that the model predicts for transnational versus domestic Moroccan entrepreneurs. With all other business and individual characteristics being equal, transnational entrepreneurs engage, on average, in one more type of socio-relational transnational activity with Morocco (about four activities) compared to domestic entrepreneurs (about three activities). Similarly, the average transnational entrepreneur engages in two types of socio-relational transnational activities with third countries, while the average domestic entrepreneur engages in one. Interestingly, the context of reception does not seem to make any difference, with Moroccan transnational entrepreneurs in Amsterdam and Milan showing the same average levels of socio-relational transnationalism. Poisson regression models for the degree of transnational involvement in the economic and political domain show no significant differences between transnational and domestic entrepreneurs (results not shown), similar to the bivariate analysis.

The qualitative interviews reveal some of the reasons and processes behind the higher level of socio-relational transnational involvement among transnational entrepreneurs. Such involvement seems mainly linked to business relations, including relations with customers, suppliers, and other business partners abroad. Some of the contacts that Moroccan transnational entrepreneurs establish for business reasons, in Morocco or in third countries, later become friends. This is reported by several entrepreneurs among our research participants:

For the business, I developed relationships that I can define as friendships. For example, when I go to China, they are happy to meet me, we go out, to have dinner, visit places, etc. (M07) 
Table 2. Poisson regressions.

\begin{tabular}{lcrrr}
\hline Variables & & Model 1 & & Model 2 \\
& B & SE & B & $0.47 * *$ \\
\hline Transnational entrepreneur & $0.29 *$ & 0.15 & 0.22 \\
Type of business (0-ethnic; 1-mainstream) & 0.18 & 0.14 & 0.17 & 0.21 \\
Business age (years since business initiation) & 0.22 & 0.15 & $0.60 * * *$ & 0.24 \\
City (0-Milan; 1-Amsterdam) & -0.14 & 0.15 & -0.03 & 0.23 \\
Sex (0-female; 1-male;) & 0.02 & 0.16 & -0.11 & 0.24 \\
Marital status (0-non-married; 1-married) & -0.09 & 0.20 & -0.33 & 0.30 \\
Medium-high education level & 0.07 & 0.16 & $0.69 * *$ & 0.29 \\
Age at migration & $-0.02 *$ & 0.01 & -0.01 & 0.01 \\
Number of years since migration & 0.02 & 0.02 & 0.04 & 0.03 \\
Number of close relatives in the destination country & -0.01 & 0.01 & -0.01 \\
Constant & $1.08 *$ & 0.49 & -1.05 \\
$N$ & 70 & 70 & 0.01 \\
R2 & 0.0471 & 0.1066 & 0.75 \\
\hline
\end{tabular}

Notes: Dependent variable is the degree of socio-relational transnational practices with Morocco (Model 1) or other countries (Model 2). Age is not included because it is highly correlated with age at migration $(r=0.7, p=0.00)$ and number of years since migration $(r=0.6$, $\mathrm{p}=0.00)$. ${ }^{*} \mathrm{p}<0.05$; $^{* *} \mathrm{p}<0.03$; $^{* * *} \mathrm{p}<0.01$.
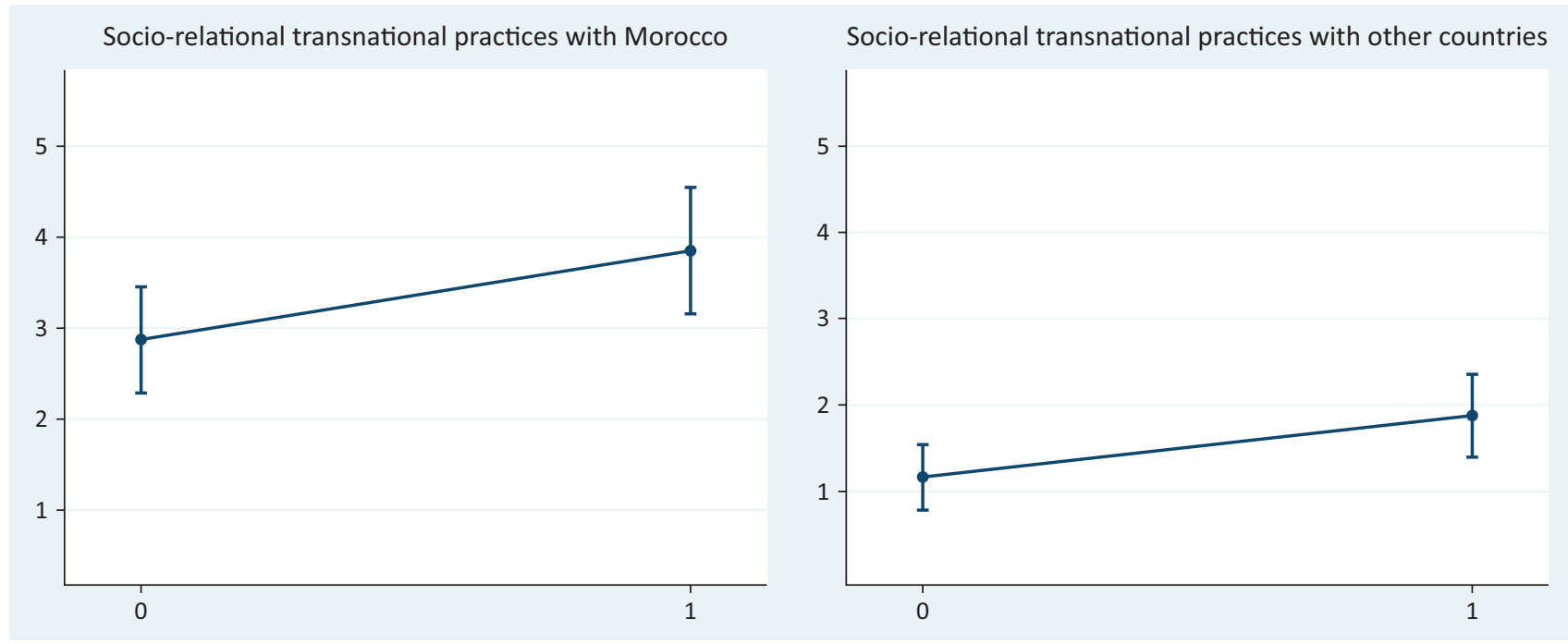

Figure 1. Predicted counts of socio-relational transnational practices with Morocco and third countries (Y-axis) for domestic (0) and transnational (1) entrepreneurs (X-axis) from models in Table 2.

After working with a person for a while, you establish a friendship. I have become friends with one of my clients. I have a very dear Indian friend who works in the Emirates for a client. We established a friendship that goes beyond the work. (M09)

It is clear that having to deal with people abroad for work you cannot help but also develop personal relationships with the people you deal with. So, I developed relations as a friend with some business contacts. We chat beyond work. (M40)

I do think it has led me to develop more contacts abroad. If you have business contacts abroad, especially for a longer period of time, non-business contacts tend to form around those. For example, you are going to dinner with a business contact, and that person invites more people, then you create contacts with other people. (A11)

I think my contacts have been slightly increased because many of the people I met for the business are now almost friends for me. And sometimes I keep in contact with them also not for business issues. (A13)

I meet new people [living abroad] every day for the business, and sometimes they become friends. (A26)

Transnational entrepreneurs' more frequent and longer trips to Morocco seem due to the fact that when entrepreneurs travel abroad for work, they also take more time to enjoy Morocco and spend leisure time there. 
This combination of work and leisure time in the origin country emerges in multiple interviews with Moroccan transnational entrepreneurs. M11, who imports and retails Arab clothes for women, is a case in point. When she goes to Morocco to buy clothes and other products, she often spends "time with people there, visit[s] several places....It's a combination of work and leisure though." The same goes for M12, a courier between Italy and Morocco: "[I] started the business to maintain links with Morocco and my city of origin. When I go there to bring the stuff, I always stay there more than I would need to stay for the business." Interestingly, M12 is the only case in which the entrepreneur deliberately chose the transnational business to keep contacts with people in Morocco. In M12's story, a pre-existing high involvement in transnational social networks leads the migrant to start a transnational business. In most other cases, however, the opposite causal direction is at work, with the migrants' transnational businesses leading them to travel more and establish more social ties with Morocco and other countries.

In contrast, interviews with domestic entrepreneurs describe a business that more firmly ties the migrant entrepreneur to the destination country (the Netherlands or Italy) and does not facilitate social contacts abroad or other transnational activities. When asked if there had been any change in their contacts and activities abroad related to their business, research participants with domestic businesses reported no change or even a decrease in transnational involvement:

No, I have my business here....Everything is here now. I have less contact with Morocco than before. (M22)

No, not at all. It stayed the same as I have no business connection abroad. (A10)

\subsection{How Does Transnational Entrepreneurship Influence Migrants' Sense of Belonging?}

No significant differences emerged between transnational and domestic entrepreneurs in terms of the sense of belonging, either in the bivariate analysis (Table A3 in the Supplementary File) or in the regression analyses (results not reported). During the interviews, participants suggested some of the reasons behind these results. They made clear that their sense of belonging is by and large not related to the business, whose establishment and development did not change the extent to which they feel close to any given place or group. In particular, almost every transnational entrepreneur we interviewed indicated that their business had not changed their feelings towards particular groups or places. The entrepreneurial activity, be it transnational or domestic, is perceived by migrant entrepreneurs as mostly related to "work" and "money," with little bearing on deeper feelings and identities. According to M04, the owner of an import/export business in Milan, "my feelings haven't
changed....They are not really influenced by my business. The business is a way to earn money, that's it." Comments by other participants who own a transnational business reveal a similar view:

The business is just work, it doesn't change you.... don't think that my feelings have changed since or due to the business start-up. (M06)

I have my feelings, for example, I consider myself really close to Italy and Italians... but this is linked to the fact that I have been in Italy for 25 years. If I had conducted another kind of business, I would have had the same feelings. (M07)

My feelings are not changed due to business activity, they stayed the same. I don't think that conducting the business changes your feelings. (A20)

The same goes for domestic entrepreneurs, who affirmed that the business has not considerably changed the way they feel towards different places and groups. For example, M34, who owns a bakery in Milan, explained that she feels "close to Italy, but this is linked to my husband and my daughter." A19, a greengrocer in Amsterdam, expressed a similar idea: "I really feel like an Amsterdammer [a person living in Amsterdam]. I really like the country but especially the city. But the business hasn't changed much. I already loved it here. And I still do."

Therefore, overall, conducting a transnational business does not seem to have an impact on migrants' sense of belonging. However, interesting differences emerge when more closely examining the sense of attachment to different groups and places among transnational and domestic entrepreneurs. For example, we tested whether transnational entrepreneurs tend to report higher closeness scores to native-born people than they do to Moroccan migrants. We then conducted the same analysis for domestic entrepreneurs. We found three main results (Table 3 ). First, Moroccan entrepreneurs generally tend to feel closer to native-born individuals in destination countries, than to other Moroccan immigrants. This holds for both domestic and transnational entrepreneurs. Second, Moroccan entrepreneurs feel closer to Moroccan migrants than they do to immigrants in general. This pattern is also similar among both domestic and transnational entrepreneurs.

Third, Moroccan domestic entrepreneurs feel closer to both natives and Moroccans in general than they do to Moroccan migrants. This result does not hold for transnational entrepreneurs, who report similar levels of closeness to Moroccan migrants, natives, and Moroccans in general. Interviews with Moroccan domestic entrepreneurs suggest some of the reasons behind this difference. Domestic entrepreneurs often recount business-related problems they had with other Moroccan migrants in the Netherlands or Italy: 
Table 3. Comparison between the sense of belonging towards different groups.

\begin{tabular}{|c|c|c|c|c|}
\hline Sense of belonging to $(0-10)$ & Median & Mean & $\mathbf{Z}$ & $\mathbf{p}$ \\
\hline \multicolumn{5}{|c|}{ Natives vs. non-Moroccan migrants } \\
\hline \multicolumn{5}{|c|}{ Domestic entrepreneurs } \\
\hline Natives & 8 & 7.63 & \multirow{2}{*}{4.34} & \multirow{2}{*}{0.00} \\
\hline Non-Moroccan migrants & 6 & 5.71 & & \\
\hline \multicolumn{5}{|l|}{ Transnational entrepreneurs } \\
\hline Natives & 8 & 7.22 & \multirow{2}{*}{3.74} & \multirow{2}{*}{0.00} \\
\hline Non-Moroccan migrants & 6 & 5.83 & & \\
\hline \multicolumn{5}{|l|}{ Natives vs. Moroccan migrants } \\
\hline \multicolumn{5}{|l|}{ Domestic entrepreneurs } \\
\hline Natives & 8 & 7.63 & \multirow{2}{*}{2.72} & \multirow{2}{*}{0.01} \\
\hline Moroccan migrants & 7 & 6.26 & & \\
\hline \multicolumn{5}{|l|}{ Transnational entrepreneurs } \\
\hline Natives & 8 & 7.22 & \multirow{2}{*}{0.50} & \multirow{2}{*}{0.62} \\
\hline Moroccan migrants & 8 & 6.63 & & \\
\hline \multicolumn{5}{|c|}{ Moroccan group in general vs. Moroccan migrants } \\
\hline \multicolumn{5}{|c|}{ Domestic entrepreneurs } \\
\hline Moroccan group in general & 8 & 7.63 & \multirow{2}{*}{2.86} & \multirow{2}{*}{0.01} \\
\hline Moroccan migrants & 8 & 7.51 & & \\
\hline \multicolumn{5}{|l|}{ Transnational entrepreneurs } \\
\hline Moroccan group in general & 8 & 7.22 & \multirow{2}{*}{1.19} & \multirow{2}{*}{0.23} \\
\hline Moroccan migrants & 8 & 7.26 & & \\
\hline \multicolumn{5}{|c|}{ Non-Moroccan migrants vs. Moroccan migrants } \\
\hline \multicolumn{5}{|c|}{ Domestic entrepreneurs } \\
\hline Non-Moroccan migrants & 6 & 5.71 & \multirow{2}{*}{-1.81} & \multirow{2}{*}{0.07} \\
\hline Moroccan migrants & 8 & 7.51 & & \\
\hline \multicolumn{5}{|l|}{ Transnational entrepreneurs } \\
\hline Non-Moroccan migrants & 6 & 5.83 & \multirow{2}{*}{-2.43} & \multirow{2}{*}{0.02} \\
\hline Moroccan migrants & 8 & 7.26 & & \\
\hline
\end{tabular}

Notes: $Z$ and $p$ are the test statistic and $p$-value, respectively, from Wilcoxon matched-pairs signed-ranks tests. Bold $p$-value indicates test significance at $5 \%$ level.

It changed my attitude towards Moroccans here. As soon as I started earning some money, they started to ask for favours. They approached me for interest. So, now I don't feel very close to them. (M19)

I saw many co-nationals misbehaving...especially for my business. So I don't like when they do it. (M36)

When I opened the business, I got more in touch with more and more Dutch people so my feelings towards Holland became more and more positive. People are so nice and open. Moroccan people talk behind each other back and Dutch people just say what they think. (A21)

These interviews suggest that excessive expectations and claims made by co-national social networks to successful migrant entrepreneurs ("they started to ask for favours"), as well as business-related competition and conflicts with other Moroccan migrants, may lead to lower attachment of domestic entrepreneurs to co-national migrants. On the other hand, negative experiences with co-national migrants are not common in the narratives of transnational entrepreneurs. Only M15, who owns a translation business, mentioned that "through the business, I also saw the bad side of my co-nationals and this made me change my attitude towards Moroccans here." This is not casual, however, as M15 is the research participant whose transnational business is the most similar to a domestic one: While she maintains professional connections with embassies around Europe, her clientele is mostly local.

As for feelings towards different places, we found that transnational entrepreneurs are less attached to their destination neighbourhood than they are to the destination city and country, while this difference does not hold for domestic entrepreneurs. This is confirmed by the qualitative interviews. Domestic entrepreneurs in the sample frequently stress that they feel close to their destination neighbourhood and explain how this is in part linked to their business. For example, M30 owns a café in Milan. Her shop is now "a meeting point for the neighbours...especially the elders. They come inside the café to chat, ask for some help or a favour. For example, I keep the keys of their apartments when they are on holiday...just in case." She explains that "thanks to that, I really feel at home here in the area." Similar dynamics were found in other stories, such as M37's, who is a hair- 
Table 4. Comparison between the sense of belonging towards different places.

\begin{tabular}{|c|c|c|c|c|}
\hline Sense of belonging to $(0-10)$ & Median & Mean & $\mathbf{Z}$ & $\mathbf{p}$ \\
\hline \multicolumn{5}{|c|}{ Destination neighbourhood vs. destination country } \\
\hline \multicolumn{5}{|c|}{ Domestic entrepreneurs } \\
\hline Destination neighbourhood & 8 & 7.14 & -0.74 & 0.46 \\
\hline Destination country & 8 & 7.7 & & \\
\hline \multicolumn{5}{|l|}{ Transnational entrepreneurs } \\
\hline Destination neighbourhood & 7 & 6.3 & -2.75 & 0.01 \\
\hline Destination country & 8 & 7.5 & & \\
\hline \multicolumn{5}{|c|}{ Destination neighbourhood vs. destination city } \\
\hline \multicolumn{5}{|c|}{ Domestic entrepreneurs } \\
\hline Destination neighbourhood & 8 & 7.14 & -1.19 & 0.24 \\
\hline Destination city & 8 & 7.77 & & \\
\hline \multicolumn{5}{|l|}{ Transnational entrepreneurs } \\
\hline Destination neighbourhood & 7 & 6.3 & -2.86 & 0.01 \\
\hline Destination city & 8 & 7.57 & & \\
\hline
\end{tabular}

Notes: $Z$ and $p$ are the test statistic and $p$-value, respectively, from Wilcoxon matched-pairs signed-ranks tests. Bold $p$-value indicates test significance at $5 \%$ level.

dresser, and A01's, who owns a fish shop. By contrast, the neighbourhood dimension does not appear in the narratives of the transnational entrepreneurs we interviewed.

In conclusion, running a domestic business seems to play a significant role in shaping migrants' local identifications-e.g., toward the destination neighbourhood or co-national immigrants. By contrast, this link is less pronounced when it comes to transnational entrepreneurs.

Our data collection took place in 2013-2014, immediately after the Arab Spring events (2010-2012) produced historical political and social changes in North African and Middle Eastern countries, including Morocco. While one may suspect that these historical events may have substantially changed Moroccan entrepreneurs' feelings and attitudes towards Morocco, our respondents clarified at multiple points in the interviews that the Arab Spring and the evolving Moroccan political situation did not influence their (concrete and emotional) links with the country.

\section{Discussion and Conclusion}

This article compared Moroccan migrant entrepreneurs with domestic and transnational businesses to answer the question of whether transnational entrepreneurship fundamentally changes migrants' transnational practices in other domains, as well as their sense of belonging to different places and social groups. We used data from mixed-methods research with Moroccan entrepreneurs in two European cities that have become major destinations of immigration to Europe-Amsterdam and Milan.

We found that transnational entrepreneurship has a significant influence on migrants' transnational practices and sense of belonging, but one that is mostly limited to the socio-relational domain. Our starting hypothesis, that transnational entrepreneurs conduct more transnational activities across different domains of social life, is only partially supported. Compared to their domestic counterparts, Moroccan transnational entrepreneurs show more transnational involvement in the socio-relational dimension, with more frequent or intense practices such as travelling abroad (to Morocco or third countries) and maintaining social ties with third countries. However, we found no systematic differences between transnational and domestic entrepreneurs concerning political and economic transnational practices not related to the business. Thus, while some previous research has suggested that transnational economic activities are positively associated with transnational practices in other domains (e.g., van Bochove et al., 2010), our results indicate that this does not extend to transnational business activities, at least in the case of Moroccan entrepreneurs.

Previous literature (e.g., Brzozowski et al., 2017; Portes et al., 2002) has mostly studied transnational entrepreneurship as a form of social and economic adaptation in receiving countries. Our findings show that transnational entrepreneurship also increases engagement in socio-relational practices with the origin of society and third countries. This increase seems strictly related to the business. Research participants who own transnational businesses explain that when they travel or establish contacts abroad for business reasons, new opportunities arise for visiting and staying in Morocco, as well as for developing friendships that go beyond business and market transactions. We also find that the longer a business has been in place, the higher the socio-relational transnational involvement of migrant entrepreneurs is with third countries, while there is no similar effect on socio-relational transnationalism with the origin country. This suggests that (transnational) business activities lead migrants to develop increasingly heterogeneous and extensive cross-border ties, involving 
multiple countries other than the destination country (Solano, 2019). Furthermore, the transnational involvement of Moroccan entrepreneurs does not vary by business industry or sector.

Adopting González-Rábago and Blanco's (2016) classification of transnationalism spheres, our results suggest that the social spheres of transnationalism (interest in Morocco, voting, and associative behaviours) are not particularly influenced by transnational entrepreneurship. By contrast, transnational businesses have a substantial influence on the personal spheres of action, with transnational entrepreneurs spending more time visiting relatives and friends and supporting people in Morocco more frequently than domestic entrepreneurs. The business seems to have an impact on the personal interest sphere too, but to a lesser extent as transnational entrepreneurs' cross-border social contacts are more frequent only with people living in third countries. On the other hand, transnational entrepreneurs in our sample do not report more frequent contacts with family and friends in the origin country. This is consistent with Engbersen and colleagues' (2013) findings that, in the Netherlands, "bi-national" migrants (similar to transnational entrepreneurs in our study) have as many contacts as "settlers" (analogous to domestic entrepreneurs) with family and friends in the origin country.

We consistently find the same association between transnational entrepreneurship and socio-relational transnationalism among Moroccan immigrants in both Amsterdam and Milan. Thus, this relationship does not seem to be fundamentally altered by differences between migrants' reception contexts (e.g., different size of the Moroccan population in Amsterdam versus Milan).

Conducting a transnational business, on the other hand, does not appear to affect migrants' sense of belonging. Participants in our research explain that the business does not essentially change their perceptions of different groups and places, because "it is just work." Thus, our expectation that transnational entrepreneurs develop a different sense of belonging compared to domestic entrepreneurs is not supported. These results are in partial contrast with Snel et al.'s (2016) finding that transnational economic activities are associated with greater identification with co-nationals in the origin country. The question of whether and how transnational economic activities, including entrepreneurship, influence migrants' identities and sense of belonging has important policy implications and merits further research. A recurrent, sometimes implicit idea in public and political discourse about migrant transnationalism is that transnational involvement facilitates identification with origin communities and co-ethnic groups at the expense of receiving countries and societies. This would allegedly promote mixed loyalties that are in contrast with the principles of citizenship in destination countries (Bloemraad, Korteweg, \& Yurdakul, 2008). Our findings do not support this idea, showing that Moroccan transnational entrepreneurs maintain similar types of identi- ties and sense of belonging as domestic entrepreneurs. In policymaking, this suggests that transnational entrepreneurship could be supported as a viable migrant adaptation strategy that would not be in conflict with migrants" "loyalty" to destination countries.

Our results are also in line with previous literature showing that transnational entrepreneurs generally start their business for reasons of economic and financial opportunity, and as a vehicle of empowerment, rather than to remain connected with or do something for their origin communities (Rusinovic, 2008; Solano, 2019; Vershinina, Rodgers, Mcadam, \& Clinton, 2019). The increased transnational contacts with Morocco or third countries are a by-product, rather than an intended goal, of transnational entrepreneurship. This seems to contradict, at least in part, the argument made by recent literature on Moroccan migration (de Haas, 2009; de Haas \& Fokkema, 2011) that economic integration and transnational ties are often a way to maintain links with and return to the homeland.

On a final note, this study's limitations, including the use of a non-probability sample, the focus on a single national group, and the cross-sectional data, suggest multiple avenues for future research. Further quantitative research based on larger probability samples and including either multiple national groups or multiple time points would provide more robust and generalisable results. A longitudinal approach would also help to disentangle the direction of causality between transnational entrepreneurship, on the one hand, and overall transnational involvement and sense of belonging, on the other.

\section{Acknowledgments}

This work was supported by a doctoral scholarship from the Italian Ministry of Education and a mobility scholarship from the European Commission (Erasmus Placement/Erasmus+ Traineeship). Furthermore, Fondazione Roberto Franceschi Onlus and Fondazione Isacchi Samaja (Young Professional Grant-2013 edition) provided the financial support for the fieldwork on which this article is based. This publication was supported by Université Libre de Bruxelles in the context of the project "Integration of Migrant Entrepreneurs in Brussels."

\section{Conflict of Interests}

The authors declare no conflict of interests.

\section{Supplementary Material}

Supplementary material for this article is available online in the format provided by the authors (unedited).

\section{References}

Ambrosini, M. (2012). Migrants' entrepreneurship in transnational social fields: Research in the Italian 
context. International Review of Sociology, 22(2), 273-292.

Andreotti, A., \& Solano, G. (2019). The use of new technologies by migrant entrepreneurs in two European cities. In M. Elo \& I. Minto-Coy (Eds.), Diaspora networks in international business (pp. 449-467). Cham: Springer.

Bijwaard, G. E. (2010). Immigrant migration dynamics model for the Netherlands. Journal of Population Economics, 23(4), 1213-1247.

Bloemraad, I., Korteweg, A., \& Yurdakul, G. (2008). Citizenship and immigration: Multiculturalism, assimilation, and challenges to the nation-state. Annual Review of Sociology, 34(1), 153-179.

Boccagni, P. (2012). Rethinking transnational studies: Transnational ties and the transnationalism of everyday life. European Journal of Social Theory, 15(1), 117-132.

Brzozowski, J., Cucculelli, M., \& Surdej, A. (2017). The determinants of transnational entrepreneurship and transnational ties' dynamics among immigrant entrepreneurs in ICT sector in Italy. International Migration, 55(3), 105-125.

Chamber of Commerce of Amsterdam. (2009). Data on migrant entrepreneurs. Kvk. Retrieved from www. kvk.nl

Chamber of Commerce of Milan. (2019). Milano produttiva [Productive Milan]. Milan: Chamber of Commerce of Milan.

Centraal Bureau voor de Statistiek. (2019). Population; sex, age, migration background and generation. Centraal Bureau voor de Statistiek. Retrieved from https://opendata.cbs.nl/statline/\#/CBS/en/dataset/ 37325eng/table?ts=1579095252669

Colombo, A., \& Sciortino, G. (2004). Italian immigration: The origins, nature and evolution of Italy's migratory systems. Journal of Modern Italian Studies, 9(1), 49-70.

de Haas, H. (2009). International migration and regional development in Morocco: A review. Journal of Ethnic and Migration Studies, 35(10), 1571-1593.

de Haas, H., \& Fokkema, T. (2011). The effects of integration and transnational ties on international return migration intentions. Demographic Research, 25, 755-782.

Diaz-Chorne, L., Suárez-Lledó, V., \& Rodriguez, J. L. (2019). It's the taking part that counts: Inequalities and simultaneous youth transnational engagement from six European countries. Migration Letters, 16(1), 73-91.

Ehrkamp, P. (2005). Placing identities: Transnational practices and local attachments of Turkish immigrants in Germany. Journal of Ethnic and Migration Studies, 31(2), 345-364.

Engbersen, G., Leerkes, A., Grabowska-Lusinska, I., Snel, E., \& Burgers, J. (2013). On the differential attachments of migrants from Central and Eastern Europe: A typology of labour migration. Journal of Ethnic and
Migration Studies, 39(6), 959-981.

Erdal, M. B., \& Oeppen, C. (2013). Migrant balancing acts: Understanding the interactions between integration and transnationalism. Journal of Ethnic and Migration Studies, 39(6), 867-884.

González-Rábago, Y., \& Blanco, C. (2016). Modes of engagement of immigrants with their home societies: Types and measurements of engagement. Journal of Ethnic and Migration Studies, 42(5), 857-876.

Groenewold, G., \& de Valk, H. A. G. (2017). Acculturation style, transnational behaviour, and return-migration intentions of the Turkish second generation: Exploring linkages. Demographic Research, 37, 1707-1734.

Guarnizo, L. E., Portes, A., \& Haller, W. (2003). Assimilation and transnationalism: Determinants of transnational political action among contemporary migrants. American Journal of Sociology, 108(6), 1211-1248.

Istat. (2019). Resident population by sex and demographic balance. Istat. Retrieved from http://demo. istat.it/str2018/index_e.html

Jacobs, D., Phalet, K., \& Swyngedouw, M. (2006). Political participation and associational life of Turkish residents in the capital of Europe. Turkish Studies, 7(1), 145-161.

Levitt, P. (2001). Transnational migration: Taking stock and future directions. Global Networks, 1(3), 195-216.

Levitt, P., \& Jaworsky, B. N. (2007). Transnational migration studies: Past developments and future trends. Annual Review of Sociology, 33(1), 129-156.

Ley, D. (2013). Does transnationalism trump immigrant integration? Evidence from Canada's links with East Asia. Journal of Ethnic and Migration Studies, 39(6), 921-938.

Louie, V. (2006). Growing up ethnic in transnational worlds: Identities among second-generation Chinese and Dominicans. Identities: Global Studies in Culture and Power, 13(3), 363-394.

OECD. (2010). Open for business. Paris: OECD.

Phalet, K., \& Swyngedouw, M. (2002). National identities and representations of citizenship: A comparison of Turks, Moroccans and working-class Belgians in Brussels. Ethnicities, 2(1), 5-30.

Portes, A., Guarnizo, L. E., \& Haller, W. J. (2002). Transnational entrepreneurs: An alternative form of immigrant economic adaptation. American Sociological Review, 67(2), 278-298.

Rath, J., \& Eurofound. (2011). Promoting ethnic entrepreneurship in European cities. Luxembourg: Publications Office of the European Union.

Rath, J., \& Schutjens, V. (2016). Migrant entrepreneurship: Alternative paradigms of economic integration. In A. Triandafyllidou (Ed.), Routledge handbook of immigration and refugee studies (pp. 96-103). Abingdon and New York, NY: Routledge.

Rath, J., Solano, G., \& Schutjens, V. (2020). Migrant entrepreneurship and transnational links. In C. Inglis, W. Li, \& B. Khadria (Eds.), Sage handbook of interna- 
tional migration (pp. 450-465). London: Sage.

Ren, N., \& Liu, H. (2015). Traversing between transnationalism and integration: Dual embeddedness of new Chinese immigrant entrepreneurs in Singapore. Asian and Pacific Migration Journal, 24(3), 298-326.

Rouvoet, M., Eijberts, M., \& Ghorashi, H. (2017). Identification paradoxes and multiple belongings: The narratives of Italian migrants in the Netherlands. Social Inclusion, 5(1), 105-116.

Rusinovic, K. (2008). Transnational embeddedness: Transnational activities and networks among firstand second-generation immigrant entrepreneurs in the Netherlands. Journal of Ethnic and Migration Studies, 34(3), 431-451.

Silverman, D. (2013). Doing qualitative research. London and Thousand Oaks, CA: Sage.

Snel, E., Engbersen, G., \& Leerkes, A. (2006). Transnational involvement and social integration. Global Networks, 6(3), 285-308.

Snel, E., 't Hart, M., \& van Bochove, M. (2016). Reactive transnationalism: Homeland involvement in the face of discrimination. Global Networks, 16(4), 511-530.

Solano, G. (2016a). Multifocal entrepreneurial practices: The case of Moroccan import/export businesses in Milan. International Journal of Entrepreneurship and Small Business, 29(2), 176-198.

Solano, G. (2016b). Immigrant self-employment and transnational practices: The case of Moroccan en- trepreneurs in Amsterdam and Milan (Unpublished Doctoral dissertation). University of Milan-Bicocca, Milan, Italy, and University of Amsterdam, Amsterdam, the Netherlands.

Solano, G. (2019). The mixed embeddedness of transnational migrant entrepreneurs: Moroccans in Amsterdam and Milan. Journal of Ethnic and Migration Studies. Advance online publication. https://doi.org/10. 1080/1369183X.2018.1559999

Tsuda, T. (2012). Whatever happened to simultaneity? Transnational migration theory and dual engagement in sending and receiving countries. Journal of Ethnic and Migration Studies, 38(4), 631-649.

Vacca, R., Solano, G., Lubbers, M. J., Molina, J. L., \& McCarty, C. (2018). A personal network approach to the study of immigrant structural assimilation and transnationalism. Social Networks, 53, 72-89.

van Bochove, M., Rusinovic, K., \& Engbersen, G. (2010). The multiplicity of citizenship: Transnational and local practices and identifications of middle-class migrants. Global Networks, 10(3), 344-364.

Vershinina, N., Rodgers, P., Mcadam, M., \& Clinton, E. (2019). Transnational migrant entrepreneurship, gender and family business. Global Networks, 19(2), 238-260.

Wotherspoon, T. (2018). Migration, boundaries and differentiated citizenship: Contested frameworks for inclusion and exclusion. Social Inclusion, 6(3), 153-161.

\section{About the Authors}
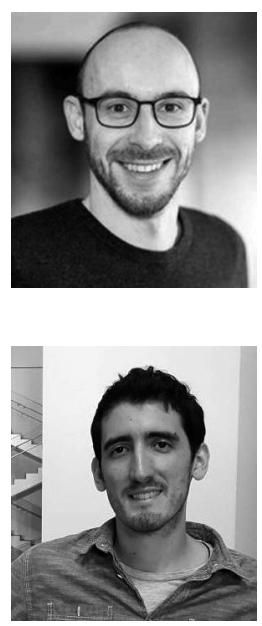

Raffaele Vacca (PhD) is Assistant Professor in the Department of Sociology and Criminology \& Law at the University of Florida, and faculty affiliate in the Clinical and Translational Science Institute and in the Bureau of Economic and Business Research in the same university. His research focuses on migration, immigrant incorporation, and health in Europe and the US, social networks, and science and scientific collaboration.

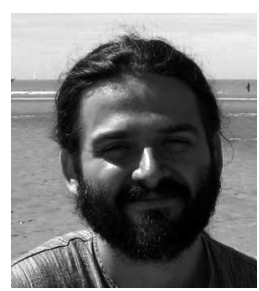

Matteo Gagliolo (PhD) is an Associate Professor at the Université Libre de Bruxelles, affiliated with the Group for Research on Ethnic Relations, Migration and Equality (GERME), Institute of Sociology. His main research interests include dynamic social network analysis, complex systems, collective behaviour, social capital, migration, multiculturalism, and inequalities. 


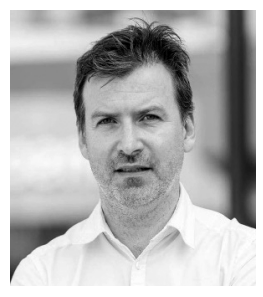

Dirk Jacobs (PhD) is Full Professor in Sociology at the Université Libre de Bruxelles and Director of the Research Group GERME (Group for Research on Ethnic Relations, Migration and Equality), Institute of Sociology. His main research interests are minority-majority relations, immigrant integration, political participation of ethnic minorities, and social stratification. 